\title{
CYBER-PHYSICAL MODEL OF THE IMMUNOSENSOR SYSTEM IN A RECTANGULAR LATTICE WITH THE USE OF LATTICE DIFFERENCE EQUATIONS OF POPULATION DYNAMICS
}

\author{
Andrii Sverstiuk
}

\author{
Ternopil State Medical University, Ternopil, Ukraine
}

\begin{abstract}
Summary. The article developed a cyber-physical model for immunosensory systems. The main attention is paid to the mathematical description of the discrete dynamics of populations in combination with dynamic logic, which is used for discrete events. A class of solvable differential equations with time delay was introduced for modeling the interaction of antigen-antibodies within immunopicles. A spatial operator was used that simulates the interaction between immunopicles similar to the diffusion phenomenon. The paper presents the results of numerical simulation in the form of images of phase planes of the immunosensor model for antibody populations, with respect to antigenic populations. The experimental results obtained make it possible to analyze the stability of the model under consideration, taking into account the time delay.
\end{abstract}

Key words: mathematical modeling, cyber-physical system, immunosensory system, biosensor, immunosensor, difference equations, stability of the model.

Statement of the problem. Cyber-physical system (CPS) is a physical system that implements the integration of calculations and physical processes. They occur mainly in the form of build-in systems and networks for monitoring and controlling physical processes in feedback systems. In such systems, the dynamics of physical processes is the source of information of the investigated phenomenon with the ability to control and calculate the signals of object control [1].

Analysis of the available investigation results. Cyber-physical systems are identified with the impact of the fourth industrial revolution that takes place in the modern world [2]. Thus, there is also a physical opportunity to use technologies «Internet of Things», where it is necessary to use signals from sensors and measuring devices. Hence, there are more and more publications [3] paying attention to modern concepts and offering new innovative solutions. A. Platzer offered an approach based on «dynamic logic», where he describes and analyzes cyber-physical systems [4], [5]. Hybrid programs (HP) are used in this papers in simple programming language with simple semantics. HPs allow the programmer to refer directly to the actual values of variables that represent real values and determine their dynamics.

The objective of the paper is to develop a cyber-physical model of the immunosensory system on a rectangular lattice using differential equations of population dynamics. Such model has the ability to control and calculate the signals of objects management in various sectors of the national economy, particularly in medicine, and completely reveals its potential in biosensors development.

Statement of the task. Mathematical model of the cyber-physical model of the immunosensory system on a rectangular lattice should take into account the spatial-temporal properties of the device in which it is used. As far as spatial organization is concerned, the 
investigated model should be based on a certain discrete structure taking into account the interaction of the immunosensor pixels. In the continual space the model should describe processes known as population dynamics. That is why the problem consists in the development of the mathematical model of the cyber-physical immunosensory system that takes into account a number of biological assumptions regarding the main device components - the colonies of antigens and antibodies localized in pixels, the diffusion of the antigens colony between pixels, and others.

Investigation results. Immunosensory systems. With the life rate growth and the need for more accurate methods for various parameters monitoring, interest in biosensors in science and industry is growing. Biosensors are the alternative to well-known measurement methods characterized by poor selectivity, high cost, poor stability, slow response, and can often be performed only by highly trained personnel. This is a new generation of sensors which use biological material in design providing very high selectivity and allowing quick and simple measurements [6], [7].

Cell biosensors can be used for quantitative evaluation of infection in the body due to certain electrochemical or optical phenomena. Cellular biosensor using electrochemical impedance spectroscopy is described in paper [8]. This biosensor is intended for counting human CD4+ cells. The sensing area of this biosensor includes electrode pixels, each is compared to the size of CD4+ cell absorbed by electrode pixels. They are detected by observing informative changes on the pixel. «On» or «Off» state of the electrode pixel indicates the detection of one CD4+ cell. Thus, in order to calculate CD4+ cells, it is necessary to summarize electrode pixels in the «On» state.

This general approach to quantitative detection of cells is used to simulate the immunosensory system based on the fluorescence phenomenon. Immunosensors [9] are the subgroup of biosensors, where the immunochemical reaction is associated with the transducer. The principle of all immunosensors is the specific molecular antigens recognition by antibodies to form the stable complex.

Cyber-physical immunosensory system (CPISS). The definition of the term «Cyberphysical sensory system (CPISS)» is given in [10]. This definition was introduced for the industrial use of sensors. The general definition of CPISS involves «a higher degree of combination, system distribution, the ability to use build-in systems in the field of automation and compliance with existing standards.» The considered approach is used to characterize CPISS (see Fig. 1) making it possible to perform its numerical simulation.

According to [10], definitions and schemes for CFSS are used to define CPISS. CPISS converts physically measured immunological indices into digital information, which enables to process signals in time using certain algorithms. There is also interaction with their own abilities, requirements, internal data and internal tasks in terms of distribution to the same or higher level of the hierarchy.

The basis of the CPISS (the external rectangle in Figure 1 is the concept of the cyber-physical system (CPS), taking into account the features of intellectual imaging sensors. With additional skills (dotted line in Figure 1), the sensor extends to CPISS enabling to get more diagnostic information about the investigated object. 


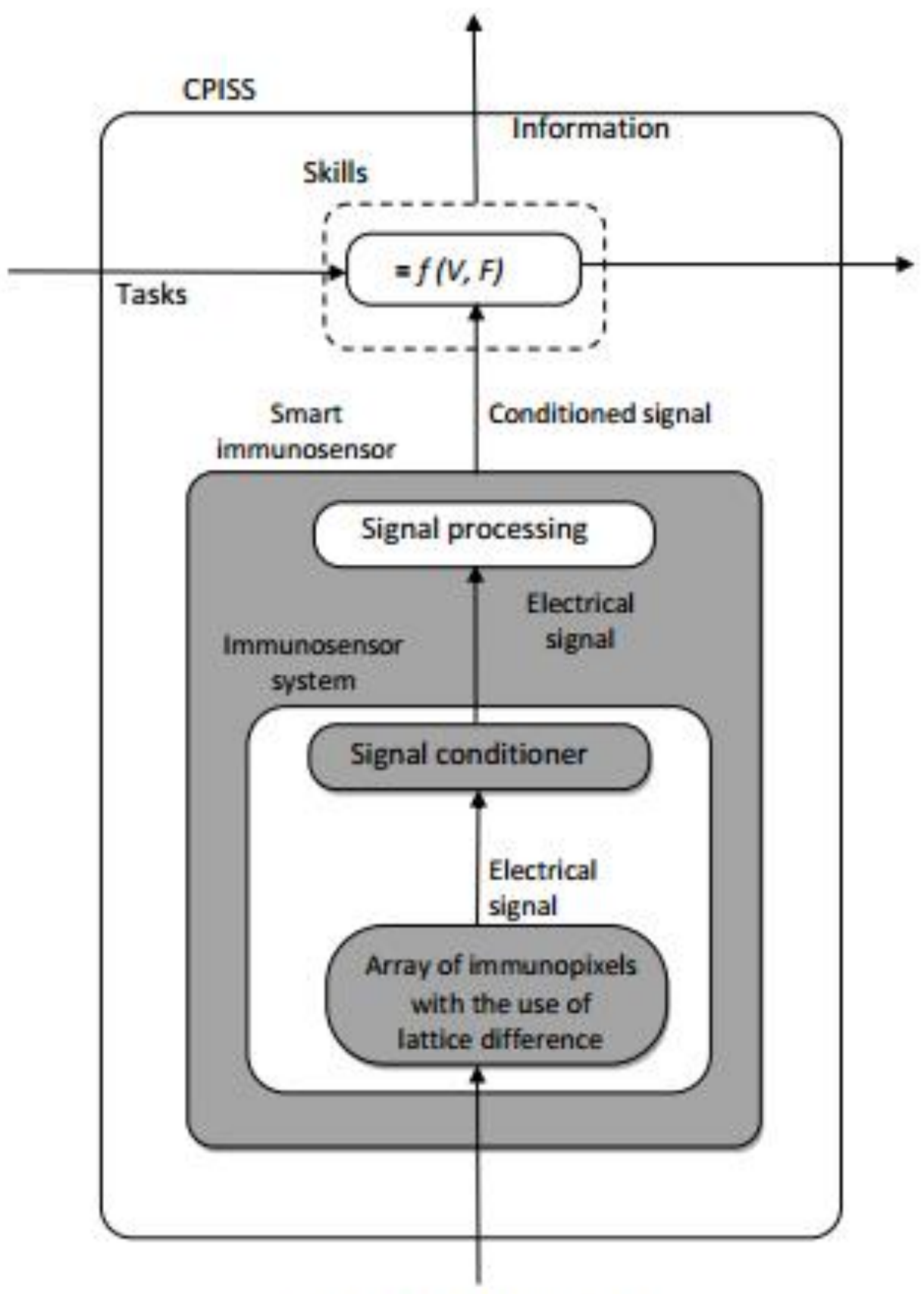

\section{Measured biological parameter}

Figure 1. Functional scheme of CPISS

In imunosensor devices there are four main types of detection: electrochemical (potentiometric, amperometric or conductometric (capacitive), optical and thermometric [9]). All types of sensors can be used as direct (unlabeled) or as indirect (labeled) imunosensors. Direct sensors can detect physical changes during the formation of immune complexes, while indirect use different generated signal levels making detection in measuring systems more sensitive and versatile

CPISS relates to high-intelligence information systems. They use available set of interfaces enabling to receive fast and accurate status information and internal system data which should be available to other CPSs. According to [10], CPISS, as a self-organizing system, 
requires profound knowledge of its own dynamic structure and infrastructure of the overall system. In order to do this, it is necessary to determine the types of immunosensory devices taking into account their functional application. For example, immunosensors can be used to evaluate critical states in cardiovascular diseases, insulin values when measuring glucose levels in blood, and to determine quantitative indices in some pharmaceutical compounds.

In [10] the general structure of the CPISS is offered. While applying this scheme in the case of immunosensors three directions can be pointed out: general information about the immunosensor; measurements of immunological parameters and skills in relation to unit conversion and calibration; interaction with other immunosensors. Thus, certain methods providing the immunosensor description are concerned. In this work the programming language $\mathrm{R}$ was used while investigating CPISS. Despite the vast variety of programming languages used in the development of the CPS (Assembly, C, C++, D, Java, JavaScript, Python, Ada etc. [11]), language $\mathrm{R}$ is widely used at present in many fields of machine learning and data visualization.

Continuous dynamics of CPISS. For continuous CPISS dynamics we use the mathematical description using nonlinear difference equations with delay. Let us denote $V_{i, j}(n)$ as antigen concentration, $F_{i, j}(n)$ as concentration of antibodies in the immune pixel $(i, j)$, $i, j=\overline{1, N}$. The model is based on the following biological assumptions for an EMBED Equation.3 immunopaccelention, EMBED Equation.3. The model is based on the following biological assumptions for $(i, j)$ immunopixel.

1. The birth rate is introduced, $\beta>0$ for the antigen population.

2. Antigens are detected, bind and finally neutralized by antibodies with some probability rate $\gamma>0$.

3. Some antibodies mortality constant $\mu_{f}>0$ is introduced.

4. It is assumed that when antibodies colonies are absent, antigens colonies are regulated by the logistic equation with delay.

5. Antibodies decrease the mean linear growth rate of antigens with a certain delay in time $\tau$; this assumption is consistent with the fact that antibodies can not instantly detect and bind antigens; antibodies have to be spend $r$ units of time before they can reduce the average rate of antigens colonies growth; these aspects are included in the dynamics of antigens, by incorporating the value $-\gamma F_{i, j}(n-r)$, where $\gamma$ is a positive constant that can vary depending on specific antibody and antigen colonies.

6 . In the absence of colonies of antigens, the average rate of growth of antibody colonies decreases exponentially, due to the value $-\mu_{f}$ in the dynamics of antibodies. In order to include the negative effects of the accumulation of antibodies, the value $-\delta_{f} F_{i, j}(n)$ in the dynamics of antibodies was introduced.

7. Positive feedback $\eta \gamma V_{i, j}(n-r)$, the average antibody growth rate has a delay since the maturity of adult antibodies can only contribute to the production of biomass antibodies; we can consider the delay $r$ in $\eta \gamma V_{i, j}(n-r)$ as a delay in antibodies maturation.

8. The diffusion of antigens between the four adjacent pixels $(i-1, j),(i+1, j)$, $(i, j-1),(i, j+1)$ (Fig. 2), diffusion $D>0$ is considered. Only the diffusion of antigens is taken into account, because the model describes the so-called «competitive» configuration of the immunosensor [12]. When considering the competitive configuration of immunosensors, factors immobilized on the biosensor matrix are antigens, while antibodies play the role of analytes or detected particles. 


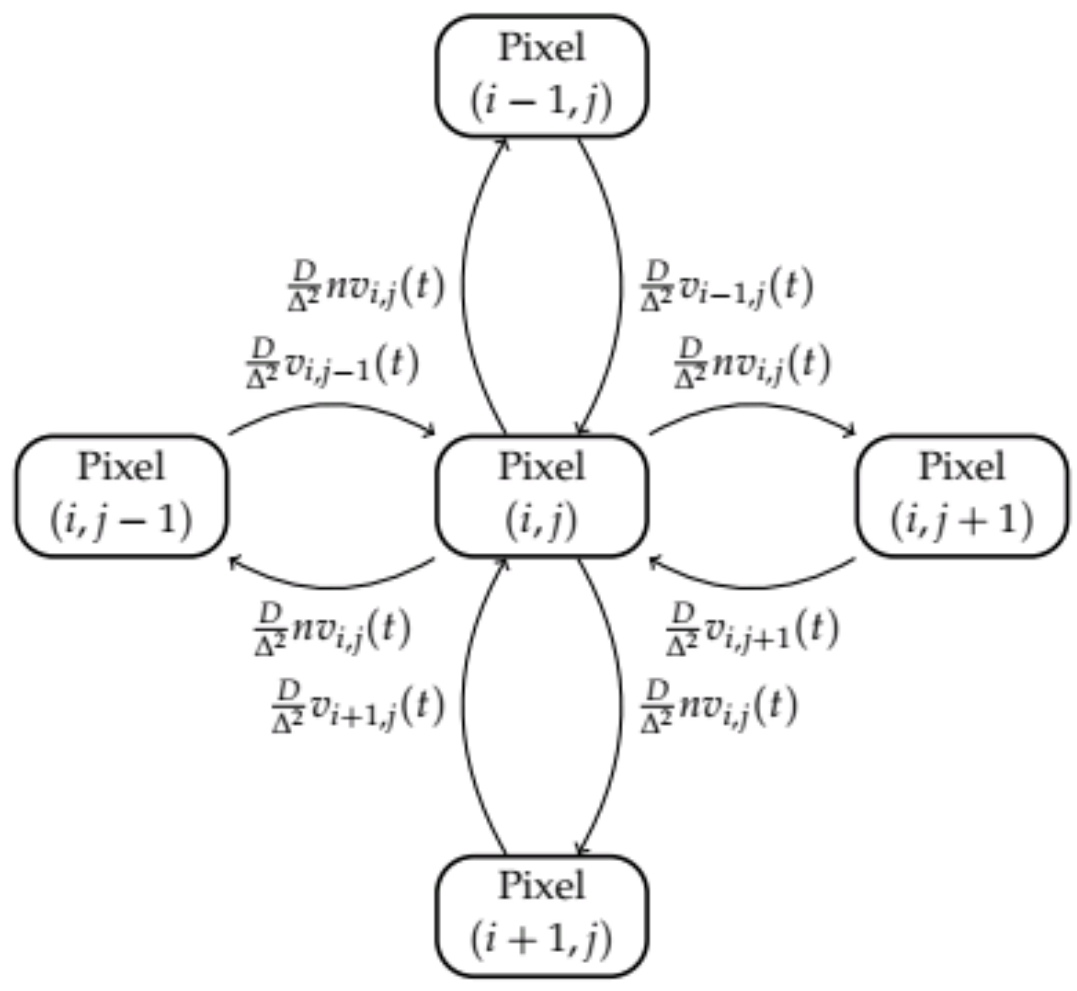

Figure 2. Linear grid, which binds four adjacent pixels in the model ( $n>0$-imbalance constant)

9. Surface diffusion (molecules motion on the solid surface for immobilized molecules) is considered [13-15].

10. The definition of the ordinary diffusion operator in the case of surface diffusion is used, $n \in(0,1]$ diffusion imbalance coefficient is introduced. This means that only the $n$-th part of the pixel antigens $(i, j)$ can be included in the diffusion process to any adjacent pixel as a result of surface diffusion.

11. As a result of antigens binding to antibodies in pixel there is a phenomenon of fluorescence. It is assumed that the fluorescence intensity is proportional to the number of contacts between the antigens and antibodies $k_{f l} V_{i, j}(n) F_{i, j}(n)$ and $(i, j)$ pixel is in a fluorescence state if

$$
k_{f l} V_{i, j}(n) F_{i, j}(n) \geq \Theta_{f l},
$$

where $\Theta_{f l}>0$ is certain threshold binding value at which a fluorescence phenomenon occurs.

12. The output signal $s(n)$ is proportional to the number of pixels in the fluorescence state.

13. Information about the number of biological measurements of values is calculated on the basis of the output signal. 
Based on the above mentioned assumptions, the antigen model for bi-pixel twodimensional array is considered, based on a well-known Marchuk immunological model [16 - 19] and the spatial operator $\hat{S}$ is proposed in [20]:

$$
\begin{aligned}
& V_{i, j}(n+1)=V_{i, j}(n) \exp \left\{\beta-\gamma F_{i, j}(n-r)-\delta_{x} V_{i, j}(n-r)\right\}+\hat{S}\left\{V_{i, j}(n)\right\}, \\
& F_{i, j}(n+1)=F_{i, j}(n) \exp \left\{-\mu_{y}+\eta \gamma V_{i, j}(n-r)-\delta_{y} F_{i, j}(n)\right\},
\end{aligned}
$$

Model (3) is given by the initial conditions (4):

$$
\begin{aligned}
& V_{i, j}(n)=V_{i, j}^{0}(n) \geq 0, \quad F_{i, j}(n)=F_{i, j}^{0}(n) \geq 0, \quad n<0, \\
& V_{i, j}(0), \quad F_{i, j}(0)>0 .
\end{aligned}
$$

For square array $N \times N$, we use such discrete diffusion for a spatial operator [20].

$$
\hat{S}\left\{V_{i, j}\right\}=\left\{\begin{array}{l}
D \Delta^{-2}\left[V_{1,2}+V_{2,1}+V_{i, j-1}-2 n V_{1,1}\right] \quad i, j=1 \\
D \Delta^{-2}\left[V_{2, j}+V_{1, j-1}+V_{1, j+1}+V_{i, j+1}-3 n V_{i, j}\right] \quad i=1, j \in \overline{2, N-1} \\
D \Delta^{-2}\left[V_{1, N-1}+V_{2, N}-2 n V_{1, N}\right] \quad i, j \in \overline{2, N-1} \\
D \Delta^{-2}\left[V_{i-1, N}+V_{i+1, N}+V_{i, N-1}-3 n V_{i, N}\right] \quad i \in \overline{2, N-1, j}=N \\
D \Delta^{-2}\left[V_{N-1, N}+V_{N, N-1}-2 n V_{N, N}\right] \quad i=N, j=N \\
D \Delta^{-2}\left[V_{N-1, j}+V_{N, j-1}+V_{N, j+1}+V_{i, j+1}-3 n V_{N, j}\right] \quad i=N, j \in \overline{2, N-1} \\
D \Delta^{-2}\left[V_{N-1,1}+V_{N, 2}-2 n V_{N, 1}\right] \quad i=N, j=1 \\
D \Delta^{-2}\left[V_{i-1,1}+V_{i+1,1}+V_{i, 2}-3 n V_{i, 1}\right] \quad i \in \overline{2, N-1}, \quad j=1 \\
D \Delta^{-2}\left[V_{i-1, j}+V_{i+1, j}+V_{i, j-1}+V_{i, j+1}-4 n V_{i, j}\right] \quad i, j \in \overline{2, N-1}
\end{array}\right.
$$

Each colony is exposed to antigens produced in four adjacent colonies - two colonies in each direction, separated by equal distances $\Delta$. We use the boundary condition for the edges array $i, j=0, N+1$.

Dynamic logical simulation of CPISS. In order to simulate the dynamic logic of CPISS, we use the syntax proposed by A. Platser for the general CPS [4]. The CPS uses the programming language for hybrid programs (HPs) that has more features than differential equations. The first level of HP is THE dynamic program defined by the following grammar

$$
\begin{aligned}
& a::=V_{i, j}(n+1)=V_{i, j}(n) \exp \left\{\beta-\gamma F_{i, j}(n-r)-\delta_{x} V_{i, j}(n-r)\right\}+\hat{S}\left\{V_{i, j}(n)\right\}, \\
& F_{i, j}(n+1)=F_{i, j}(n) \exp \left\{-\mu_{y}+\eta \gamma V_{i, j}(n-r)-\delta_{y} F_{i, j}(n)\right\} \& \Phi_{t}
\end{aligned}
$$

where $\Phi_{t}$ is an evolutionary domain constraint in the form of the formula for the logic of the first order of real arithmetic 


$$
\begin{aligned}
& \Phi_{t} \stackrel{\text { def }}{\equiv} V^{\min } \leq V_{i, j}(n) \leq V^{\max } \\
& \wedge F^{\text {min }} \leq F_{i, j}(n) \leq F^{\max } \wedge i, j=\overline{1, N} \wedge n>0
\end{aligned}
$$

The immune pixel function $(i, j)$ is determined by two states regarding fluorescence. Namely, $s_{f l}$ is the fluorescence state and $s_{n o n f l}$ is one of the non-fluorescence states. Using the first order of semantics of logic and $s \mid=L$ satisfaction ratio for the first-order formula $L$ of real arithmetic and the state $s$ we can be determine for some pixels $(i, j), i, j \in \overline{1, N}$ states $s_{f l}$ i $s_{n o n f l}$, as

$$
\begin{aligned}
& s_{f t} \mid=k_{f l} V_{i, j}(n) F_{i, j}(n) \geq \theta_{f l}, \\
& s_{n o n f l} \mid=k_{f l} V_{i, j}(n) F_{i, j}(n)<\theta_{f l}
\end{aligned}
$$

Discrete changes occur in computer programs when they accept new values for variables. This situation occurs in the case of the occurrence of the fluorescence phenomenon in the pixel $(i, j)$. The state $s_{f l, i, j}:=1$ is assigned value 1 the variable $s_{f l, i, j}$. This results in discrete, jump-free change, since the value $s_{f l, i, j}$ does not change smoothly, but rapidly when it suddenly changes from 1 to $s_{f l, i, j}$ causing discrete jump of $s_{f l, i, j}$ values.

In such a way, we obtain discrete change model $s_{f l, i, j}:=1$, except the continuous change model (6). Using this feature, you can simulate any pixel that is discrete or continuous. Hence, we need to simulate CPS that combines cybernetics and physics of each other, thus simultaneously combining discrete and continuous dynamics. We need such hybrid behavior every time when pixel has both continuous dynamics (for example, continuous population dynamics in the real world) and discrete dynamics (for example, initial measurement). Cybernetic and physical processes can interact one-sidedly if the cybernetic component provides more prioritized approach describing variables such as $F_{i, j}(0)$ for the initial density of antibodies, and the computer program determines their significance, depending on whether it measures the investigated parameter or not. That is, the cybernetic component can set the values of the parameters that influence the physical processes.

The results of digital simulation. Let us consider model (3) at: $N=16, \beta=2 \mathrm{~min}^{-1}$, $\gamma=2 \frac{m L}{\min \cdot \mu g}, \mu_{f}=1 \mathrm{~min}^{-1}, \eta=0.8 / \gamma, \delta_{v}=0.5 \frac{m L}{\min \cdot \mu g}, \delta_{f}=0.5 \frac{m L}{\min \cdot \mu g} \quad D=0.2 \frac{n m^{2}}{\min }, \cdot \Delta=0.3 \mathrm{~nm}$.

The results of numerical simulation were implemented for various values of delay in time $r$ (Figures 3, 4, 5). 

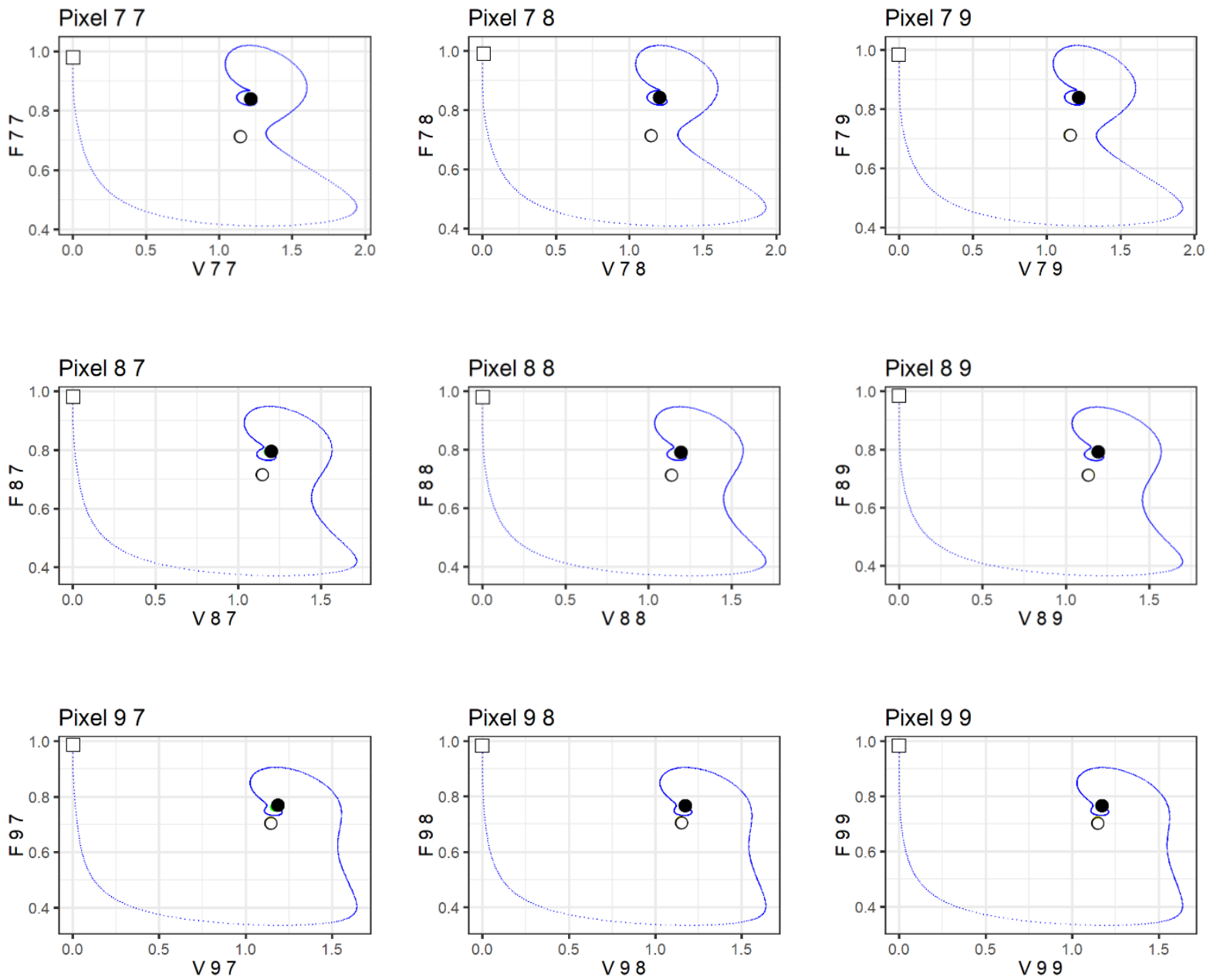

Figure 3. The phase plane plots of the system (3) or antibody populations $F_{i, j}$, relative to populations of antigens $V_{i, j}, i, j=\overline{7,9}$, as a result of numerical simulations with $r=8$. Marking: $\square$ - indicates initial state, $\circ-$ identical steady state, $\bullet$ - nonidentical steady state

The results of numerical simulation, presented in Figures 3, 4, 5, were constructed for $n \in[0,5000]$. As it can be seen from Figure 3, the solution converges to the non-identical steady state, which is the steady focus. The solution converges to the stable boundary cycle with two local extremes in the cycle are shown in Fig.5. 

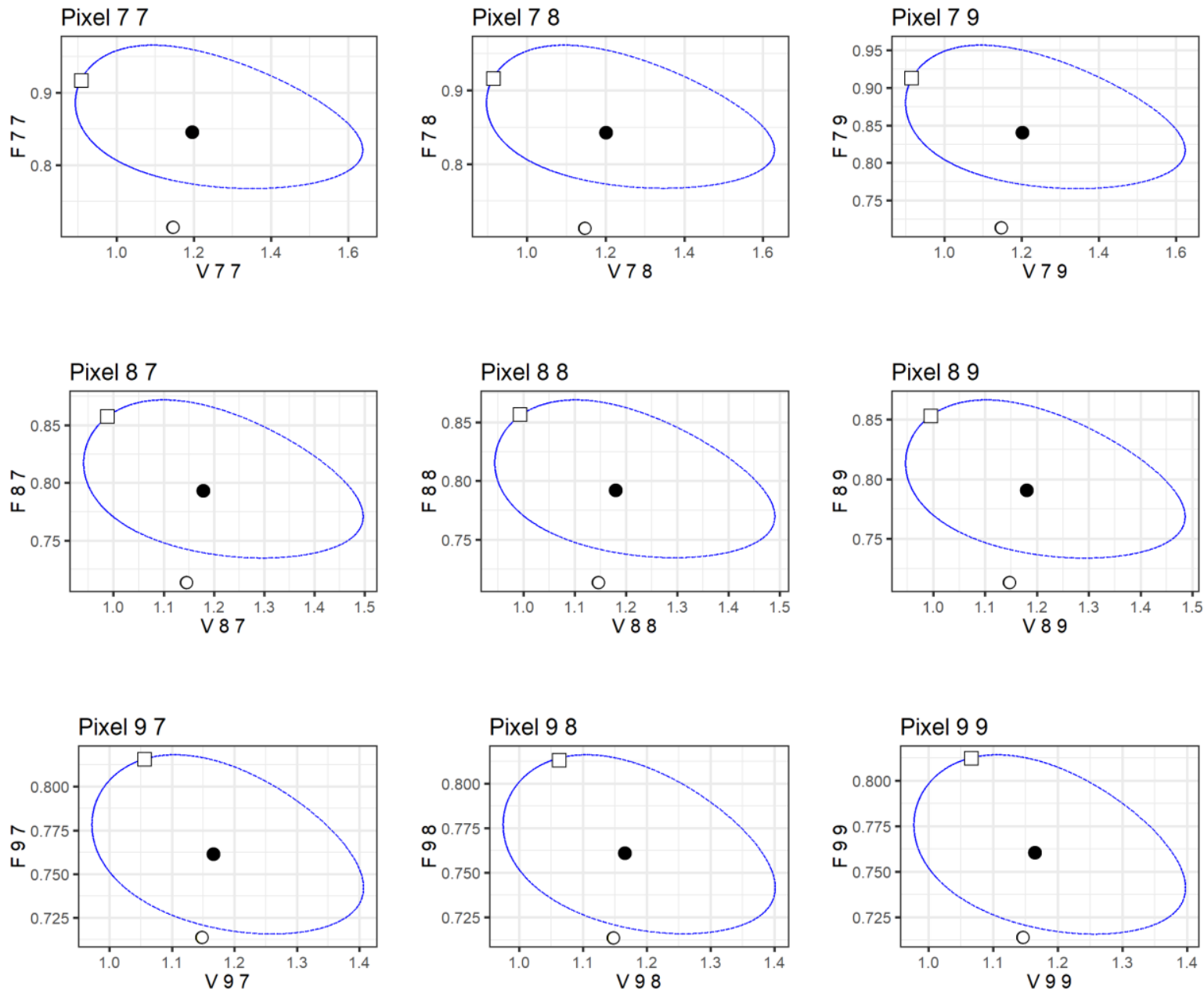

Figure 4. The phase plane plots of the system (3) or antibody populations $F_{i, j}$, relative to populations of antigens $V_{i, j}, i, j=\overline{7,9}$, as a result of numerical simulations with $r=12$. Marking: $\square$ - indicates initial state, $\circ$ - identical steady state, $\bullet-$ nonidentical steady state 

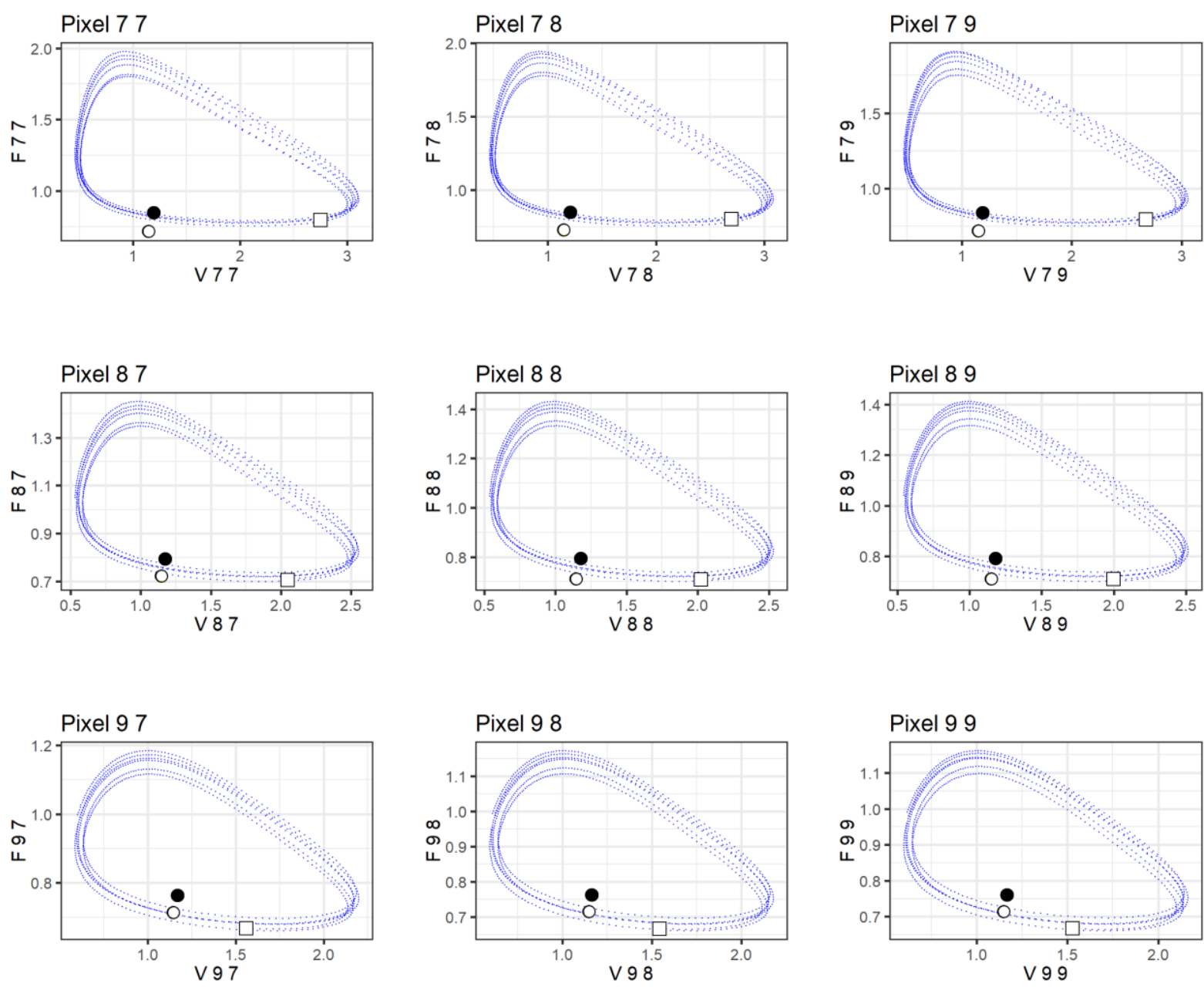

Figure 5. The phase plane plots of the system (3) or antibody populations $F_{i, j}$, relative to populations of antigens $V_{i, j}, i, j=\overline{7,9}$, as a result of numerical simulations with $r=16$. Marking: $\square-$ indicates initial state, $\circ$ - identical steady state, $\bullet-$ nonidentical steady state

Trajectories that are consistent with the steady focus for all pixels are visible in Fig.4 at $r \in[0,10)$. For $r=10$ values, Hopf bifurcation occurs [6] and the following trajectories correspond to the stable ellipsoidal boundary cycles for all pixels.

For $r=12$, the phase diagrams indicate that the solution is the boundary cycle with two local extremes (one local maximum and one local minimum per cycle). For $r=14, r=14$ solution is the boundary cycle with twelve local extremes per cycle. At $r=16$ (Figure 5), we observe chaotic behavior, i.e., the absence of any periodic behavior over a long time interval. In order to check that the solution is chaotic for $r=16$, the initial conditions were rebounded to test the sensitivity of the system. Comparison of solutions for the antigens population $V_{1,3}$ with the initial conditions $V_{1,3}(t)=1, V_{1,3}(t)=1.001, n \in[-r, 0]$ and all other identical initial conditions, demonstrate chaotic behavior. Namely, at the initial time, two solutions look identical, but with increasing time there is a difference between the solutions, which confirms the conclusion that the behavior of the system is chaotic at $r=16$. 
Conclusions. In the work, CPISS model was developed and studied in this paper. The general scheme of the cyberphysical sensory system offered in [10] was used. The basic model has been modified in order to take into account the features of immunosensors, which are considered as two-dimensional array of immune pixels. Each immunopixel is considered as cyberphysical system in order to take into account the continuous dynamics of the immunological response. Fluorescent states in immune pixels change in accordance with discrete dynamics laws. The developed model takes into account the interaction of immunopixels among themselves by antigens diffusion.

The mathematical description of CPISS contains discrete population dynamics, which is combined with the dynamic logic used for discrete events. The class of lattice variance equations with delay in time, which simulate the interaction of antigens and antibodies in immunopixels is used in this paper. The spatial operator simulates the interaction of the diffusion type between the immunopips. Dynamic mathematical modeling is not sufficient to simulate discrete dynamics in immunosensors. To overcome this shortcoming, the syntax of dynamic logic offerd for cyberphysical systems by Plattser, was used to describe the discrete states of the immunopile as the result of fluorescence.

The results of numerical simulations in the form obtained in the work allow us to analyze the stability of the model under consideration, taking into account the delay in time.

\section{References}

1. E.A. Lee, «Cyber physical systems: Design challenges,» Center for Hybrid and Embedded Software Systems, EECS University of California, Berkeley, CA 94720, USA, Tech. Rep. UCB/EECS-2008-8, Jan. 2008, p. 10. [Online]. Avail- able: https://www2.eecs.berkeley.edu/Pubs/TechRpts/2008/ EECS-20088.pdf.

2. J. Lee, B. Bagheri, and H.-A. Kao, «A cyber-physical systems architecture for industry 4.0-based manufacturing systems,» Manufacturing Letters, vol. 3, pp. 18-23, 2015, ISSN: 2213-8463. https://doi.org/ 10.1016/j.mfglet.2014.12.001

3. K.-D. Kim and P.R. Kumar, «Cyber-physical systems: A perspective at the centennial,» Proceedings of the IEEE, vol. 100, no. Special Centennial Issue, pp. 1287 - 1308, May 2012. https://doi.org/10.1109/ JPROC.2012.2189792

4. A. Platzer, «Differential dynamic logic for hybrid systems.,» J. Autom. Reas., vol. 41, no. 2, pp. 143 - 189, 2008, ISSN: 0168-7433. https://doi.org/10.1007/s10817-008-9103-8

5. Logical Foundations of Cyber-Physical Systems. Springer International Publishing, 2018.

6. V. Martsenyuk, A. Kłos-Witkowska, and A. Sverstiuk, «Stability, bifurcation and transition to chaos in a model of immunosensor based on lattice differential equations with delay,» Electronic Journal of Qualitative Theory of Differential Equations, no. 27, pp. 1 - 31, 2018. https://doi.org/10.14232/ ejqtde.2018.1.27

7. A. Kłos-Witkowska, «The phenomenon of fluorescence in immunosensors.,» Acta Biochimica Polonica, vol. 63, no. 2, 2016. https://doi.org/10.18388/abp.2015_1231

8. X. Jiang and M.G. Spencer, «Electrochemical impedance biosensor with electrode pixels for precise counting of CD4+ cells: A microchip for quantitative diagnosis of HIV infec- tion status of AIDS patients,» Biosensors and Bioelectronics, vol. 25, no. 7, pp. 1622 - 1628, Mar. 2010. https://doi.org/ 10.1016/j.bios.2009.11.024

9. P.B. Luppa, L.J. Sokoll, and D.W. Chan, «Immunosensors- principles and applications to clinical chemistry,» Clinica Chimica Acta, vol. 314, no. 1, pp. $1-26$, 2001, ISSN: 0009-8981. DOI: https://doi.org/10.1016/S0009-8981(01)00629-5. [Online]. Available: http://www.sciencedirect.com/ science/ article/pii/S0009898101006295. https://doi.org/10.1016/S0009-8981(01)00629-5 
10. C. Berger, A. Hees, S. Braunreuther, and G. Reinhart, «Characterization of cyber-physical sensor systems,» Procedia CIRP, vol. 41, pp. 638 - 643, 2016. https://doi.org/10.1016/j.procir.2015.12.019

11. P. Soulier, D. Li, and J.R. Williams, «A survey of language- based approaches to cyber-physical and embedded system development,» Tsinghua Science and Technology, vol. 20, no. 2, pp. 130 - 141, 2015. https://doi.org/10.1109/TST.2015.7085626

12. H.J. Cruz, C.C. Rosa, and A.G. Oliva, «Immunosensors for diagnostic applications,» Parasitology research, vol. 88, S. 4 - S. 7, 2002. https://doi.org/10.1007/s00436-001-0559-2

13. S.-H. Paek and W. Schramm, «Modeling of immunosen- sors under nonequilibrium conditions: I. mathematic model- ing of performance characteristics,» Analytical biochemistry, vol. 196, no. 2, pp. 319 - 325, 1991. https://doi.org/10.1016/0003-2697(91)90473-7

14. V. Bloomfield and S. Prager, «Diffusion-controlled reactions on spherical surfaces. application to bacteriophage tail fiber attachment,» Biophysical journal, vol. 27, no. 3, pp. 447 - 453, 1979. https://doi.org/10.1016/S0006-3495(79)85228-5

15. O. Berg, «Orientation constraints in diffusion-limited macro- molecular association. the role of surface diffusion as a rate- enhancing mechanism,» Biophysical journal, vol. 47, no. 1, pp. 1 - 14, 1985. https://doi.org/10.1016/S0006-3495(85)83870-4

16. G. Marchuk, R. Petrov, A. Romanyukha, and G. Bocharov, «Mathematical model of antiviral immune response. i. data analysis, generalized picture construction and parameters evaluation for hepatitis $b$,» Journal of Theoretical Biology, vol. 151, no. 1, pp. 1 - 40, 1991, cited By 38. https://doi.org/10.1016/ S0022-5193(05)80142-0

17. U. Forys, «Marchuk's model of immune system dynamics with application to tumour growth,» Journal of Theoretical Medicine, vol. 4, no. 1, pp. 85 - 93, 2002. https://doi.org/10.1080/10273660290052151

18. A. Nakonechny and V. Marzeniuk, «Uncertainties in medical processes control,» Lecture Notes in Economics and Mathe- matical Systems, vol. 581, pp. 185 - 192, 2006, cited By 2. https://doi.org/ 10.1007/3-540-35262-7_11

19. V. Marzeniuk, «Taking into account delay in the problem of immune protection of organism,» Nonlinear Analysis: Real World Applications, vol. 2, no. 4, pp. 483 - 496, 2001, cited By 2. https://doi.org/ 10.1016/S1468-1218(01)00005-0

20. A. Prindle, P. Samayoa, I. Razinkov, T. Danino, L.S. Tsim- ring, and J. Hasty, «A sensing array of radically coupled genetic 'biopixels',» Nature, vol. 481, no. 7379, pp. 39 - 44, Dec. 2011. https://doi.org/ $10.1038 /$ nature 10722

\section{Список використаної літератури}

1. E.A. Lee, «Cyber physical systems: Design challenges,» Center for Hybrid and Embedded Software Systems, EECS University of California, Berkeley, CA 94720, USA, Tech. Rep. UCB/EECS-2008-8, Jan. 2008, p. 10. [Online]. Avail- able: https://www2.eecs.berkeley.edu/Pubs/TechRpts/2008/ EECS-20088.pdf.

2. J. Lee, B. Bagheri, and H.-A. Kao, «A cyber-physical systems architecture for industry 4.0-based manufacturing systems,» Manufacturing Letters, vol. 3, pp. 18-23, 2015, ISSN: 2213-8463. https://doi.org/ 10.1016/j.mfglet.2014.12.001

3. K.-D. Kim and P.R. Kumar, «Cyber-physical systems: A perspective at the centennial,» Proceedings of the IEEE, vol. 100, no. Special Centennial Issue, pp. 1287 - 1308, May 2012. https://doi.org/10.1109/ JPROC.2012.2189792

4. A. Platzer, «Differential dynamic logic for hybrid systems.,» J. Autom. Reas., vol. 41, no. 2, pp. 143 - 189 , 2008, ISSN: 0168-7433. https://doi.org/10.1007/s10817-008-9103-8

5. Logical Foundations of Cyber-Physical Systems. Springer International Publishing, 2018.

6. V. Martsenyuk, A. Kłos-Witkowska, and A. Sverstiuk, «Stability, bifurcation and transition to chaos in a model of immunosensor based on lattice differential equations with delay,» Electronic Journal of Qualitative Theory of Differential Equations, no. 27, pp. 1 - 31, 2018. https://doi.org/10.14232/ ejqtde.2018.1.27

7. A. Kłos-Witkowska, «The phenomenon of fluorescence in immunosensors.,» Acta Biochimica Polonica, vol. 63, no. 2, 2016. https://doi.org/10.18388/abp.2015_1231 
8. X. Jiang and M.G. Spencer, «Electrochemical impedance biosensor with electrode pixels for precise counting of CD4+ cells: A microchip for quantitative diagnosis of HIV infec- tion status of AIDS patients,» Biosensors and Bioelectronics, vol. 25, no. 7, pp. 1622 - 1628, Mar. 2010. https://doi.org/ 10.1016/j.bios.2009.11.024

9. P.B. Luppa, L.J. Sokoll, and D.W. Chan, «Immunosensors- principles and applications to clinical chemistry,» Clinica Chimica Acta, vol. 314, no. 1, pp. 1 - 26, 2001, ISSN: 0009-8981. DOI: https://doi.org/10.1016/S0009-8981(01)00629-5. [Online]. Available: http://www.sciencedirect.com/ science/ article/pii/S0009898101006295. https://doi.org/10.1016/S0009-8981(01)00629-5

10. C. Berger, A. Hees, S. Braunreuther, and G. Reinhart, «Characterization of cyber-physical sensor systems,» Procedia CIRP, vol. 41, pp. 638 - 643, 2016. https://doi.org/10.1016/j.procir.2015.12.019

11. P. Soulier, D. Li, and J.R. Williams, «A survey of language- based approaches to cyber-physical and embedded system development,» Tsinghua Science and Technology, vol. 20, no. 2, pp. 130 - 141, 2015. https://doi.org/10.1109/TST.2015.7085626

12. H.J. Cruz, C.C. Rosa, and A.G. Oliva, «Immunosensors for diagnostic applications,» Parasitology research, vol. 88, S. 4 - S. 7, 2002. https://doi.org/10.1007/s00436-001-0559-2

13. S.-H. Paek and W. Schramm, «Modeling of immunosen- sors under nonequilibrium conditions: I. mathematic model- ing of performance characteristics,» Analytical biochemistry, vol. 196, no. 2, pp. 319 - 325, 1991. https://doi.org/10.1016/0003-2697(91)90473-7

14. V. Bloomfield and S. Prager, «Diffusion-controlled reactions on spherical surfaces. application to bacteriophage tail fiber attachment,» Biophysical journal, vol. 27, no. 3, pp. 447 - 453, 1979. https://doi.org/10.1016/S0006-3495(79)85228-5

15. O. Berg, «Orientation constraints in diffusion-limited macro- molecular association. the role of surface diffusion as a rate- enhancing mechanism,» Biophysical journal, vol. 47, no. 1, pp. 1 - 14, 1985. https://doi.org/10.1016/S0006-3495(85)83870-4

16. G. Marchuk, R. Petrov, A. Romanyukha, and G. Bocharov, «Mathematical model of antiviral immune response. i. data analysis, generalized picture construction and parameters evaluation for hepatitis $b$,» Journal of Theoretical Biology, vol. 151, no. 1, pp. 1 - 40, 1991, cited By 38. https://doi.org/10.1016/ S0022-5193(05)80142-0

17. U. Forys, «Marchuk's model of immune system dynamics with application to tumour growth,» Journal of Theoretical Medicine, vol. 4, no. 1, pp. 85 - 93, 2002. https://doi.org/10.1080/10273660290052151

18. A. Nakonechny and V. Marzeniuk, «Uncertainties in medical processes control,» Lecture Notes in Economics and Mathe- matical Systems, vol. 581, pp. 185 - 192, 2006, cited By 2. https://doi.org/ 10.1007/3-540-35262-7_11

19. V. Marzeniuk, «Taking into account delay in the problem of immune protection of organism,» Nonlinear Analysis: Real World Applications, vol. 2, no. 4, pp. 483 - 496, 2001, cited By 2. https://doi.org/ 10.1016/S1468-1218(01)00005-0

20. A. Prindle, P. Samayoa, I. Razinkov, T. Danino, L.S. Tsim- ring, and J. Hasty, «A sensing array of radically coupled genetic 'biopixels',» Nature, vol. 481, no. 7379, pp. 39 - 44, Dec. 2011. https://doi.org/ 10.1038 /nature 10722 


\title{
УДК 004:94:53:616-073
}

\section{КІБЕР-ФІЗИЧНА МОДЕЛЬ ІМУНОСЕНСОРНОЇ СИСТЕМИ НА ПРЯМОКУТНІЙ РЕШТЩ З ВИКОРИСТАННЯМ РІЗНИЦЕВИХ РІВНЯНЬ ПОПУЛЯЦЙНОї ДИНАМІКИ}

\author{
Андрій Сверстюк \\ Тернопільський державний медичний університет \\ імені І. Я. Горбачевського, Тернопіль, Україна
}

\begin{abstract}
Резюме. Важливим етапом проектування кібер-фізичних імуносенсорних систем є розроблення та дослідження їх моделей, при побудові яких враховуються біологічні припущення для отримання відповідних систем різницевих рівнянь популяційної динаміки. В роботі розроблено кібер-фізичну модель імуносенсорної системи на прямокутній решітиі. Для моделювання неперервної динаміки використано систему ремітчастих диференціальних рівнянь із запізненням. Для моделювання дискретних подій використано динамічну логіку першого порядку. Описано постійні стани моделі як розв'язки відповідних алгебраӥчних систем. Проведено математичне та комп'ютерне моделювання кібер-фізичної імуносенсорної системи. Математична модель дає змогу отримати значення параметрів, які б забезпечили операційну стійкість імуносенсорної системи. Висновок про стійкість кібер-фізичної моделі імуносенсорної системи на прямокутній решітиі зроблено на основі аналізу результатів комп'ютерного моделювання у вигляді відповідних фазових діаграм, отриманих з відповідної моделі. Представлено аналіз результатів чисельного моделювання досліджуваної моделі у вигляді зображення фазових площин, решітчастих зображень ймовірності зв'язків антигенів з антитілами. Встановлено, щзо їі якісна поведінка суттєво залежить від часу імунної відповіді. Отримані результати чисельного моделювання $\epsilon$ надзвичайно важливими при проектуванні кібер-фізичних імуносенсорних систем та дослідженнях їх стійкості. Граничний ичилл або стійкий фокус визначають відповідний вигляд фазових діаграм. Отримані експериментальні результати дали змогу виконати повний аналіз стійкості моделі іммуносенсора 3 урахуванням запізнення в часі.
\end{abstract}

Ключові слова: математичне моделювання, кібер-фізична система, імуносенсорна система, біосенсор, імуносенсор, різницеві рівняння, стабільність моделі. 